\title{
Analisis Makna Filosofis Motif Batik Ponorogo Sebagai Upaya Penanaman Pendidikan Karakter
}

\author{
Galih Puji Kurniawan ${ }^{1}$, Haura Almash Aulia Shofwana ${ }^{2}$ \\ ${ }^{1}$ Universitas Gadjah Mada, Indonesia \\ ${ }^{2}$ Universitas Airlangga, Indonesia
}

Corresponding Author: galihpujikurniawan@gmail.com

\section{ABSTRACT}

Ponorogo Regency has its own arts and culture which are the characteristics and identity of this Reog City. One example is batik. Batik Ponorogo has a variety of motifs that are unique and different from other regions. Ponorogo batik motifs are diverse, each of which contains a deep philosophical meaning and assumed to have relevance to the values of noble education character. The purpose of this study was describe the values of education character in the philosophical meaning of the Batik Ponorogo motif and to find out the understanding of high school students

ARTICLE INFO

Article history:

Received

May 21, 2021

Revised

July 02, 2021

Accepted

July 09, 2021 in Ponorogo Regency about the philosophical meaning of the Ponorogo batik motif on the values of education character. This study used a qualitative descriptive approach with descriptive-analytical analysis techniques. The data was obtained through in-depth interviews with batik art experts about the philosophical meaning of the Batik Ponorogo motif. Meanwhile, the data on the understanding of high school students in Ponorogo Regency regarding the philosophical meaning of batik was obtained through a questionnaire technique as supporting data. Based on the research that has been done by researchers to batik art experts, the Batik Ponorogo motif contains education character values that can be used to strengthen the students' character. In addition, from the results of the online questionnaire test that the researchers conducted on high school students in Ponorogo Regency, it was found that they were very familiar with the philosophical meanings which contained in each batik Ponorogo motif and its relevance to education character values.

Keywords: Philosophical Meaning of Batik, Education Character, Motif Batik Ponorogo

How to cite Kurniawan, G., \& Shofwana, H., (2021). Analisis Makna Filosofis Motif Batik Ponorogo Sebagai Upaya Penanaman Pendidikan Karakter. Attractive : Innovative Education Journal, 3(2). 124-137.

Journal Homepage https://www.attractivejournal.com/index.php/aj/

This is an open access article under the CC Y SA license

Published by https://creativecommons.org/licenses/by-sa/4.0/ CV. Creative Tugu Pena

\section{PENDAHULUAN}

Pendidikan adalah salah satu upaya untuk mengembangkan potensi peserta didik agar memiliki kekuatan spiritual keagamaan, pengendalian diri, memiliki kecerdasan, serta memiliki keterampilan yang diperlukan sebagai anggota masyarakat dan warga negara. Pendidikan juga merupakan proses pembentukan kepribadian peserta didik melalui nilai dan norma yang diajarkan (Maunah, 2015; Elihami, E., \& Syahid, 2018; Pohling, et al., 2018). Nilai dan norma ini nantinya dapat diterapkan dan dikembangkan dalam hidup peserta didik. Pendidikan merupakan suatu hal yang 
penting dan mutlak diperlukan bagi bangsa berkembang seperti bangsa Indonesia sejalan dengan tuntutan pembangunan nasional. Pendidikan adalah daya upaya untuk memajukan budi pekerti, pikiran, dan jasmani anak agar selaras dengan alam dan masyarakatnya (Wuryani, 2018; Kristiawan, et al., 2021; Kristiawan, et al., 2017). Dari pernyataan tersebut, dapat diketahui bahwa salah satu tujuan pendidikan nasional adalah meluluskan peserta didik yang memiliki budi pekerti luhur. Hal ini dapat diwujudkan melalui suatu pendidikan karakter sebagai pilot project dalam rangka mengembangkan kepribadian peserta didik. Fenomena saat ini, pendidikan yang berlandaskan pada kemampuan, tingkat pengetahuan, dan wawasan seseorang seakan menjadi sekat kelas sosial dalam masyarakat (Syafutra, S., Montessori, M., \& Suhono, S. 2021). Banyak orang memiliki kecerdasan, pendidikan tinggi, dan reputasi baik, tetapi tidak sedikit dari mereka yang ternyata bersifat idealis dan tidak menghargai orang lain. Kondisi itu diperparah dengan kepribadian remaja yang semakin "brutal", yaitu banyaknya kasus kenakalan remaja, seperti seks bebas, NAPZA, bullying, dan perilaku lain yang menyimpang dari norma. Kondisi tersebut mendasari pemerintah mencanangkan suatu program pendidikan karakter di seluruh Indonesia. Harapan pemerintah adalah pendidikan karakter ini mampu mengimbangi ilmu pengetahuan dan dapat diterapkan secara baik dalam kehidupan sehari-hari. Dengan demikian, ilmu-ilmu yang diterima peserta didik bermanfaat dan dapat menjadi unsur kebahagiaan bersama dalam kehidupan berbangsa dan bernegara.

Pendidikan karakter seharusnya membawa peserta didik ke pengenalan nilai secara kognitif, penghayatan nilai secara afektif, dan akhirnya ke pengamalan nilai secara nyata (Muchtar \& Suryani, 2019; Wulandari \& Kristiawan, 2017). Permasalahan yang menjadi kendala dalam pelaksanaan pendidikan karakter yang selama ini ada di sekolah perlu segera dikaji, dicari solusinya, serta perlu dikembangkan secara lebih operasional sehingga mudah diimplementasikan di sekolah. Nilai-nilai pendidikan karakter meliputi nilai religius, jujur, toleransi, disiplin, kerja keras, kreatif, mandiri, demokratis, rasa ingin tahu, semangat kebangsaan, cinta tanah air, menghargai prestasi, persahabatan atau komunikatif, cinta damai, gemar membaca, peduli lingkungan, peduli sosial, dan tanggung jawab (Cahyono, et al., 2018; Gunawan, 2019). Penanaman nilai-nilai pendidikan karakter ini tidak harus selalu melekat pada kurikulum yang diampu sekolah. Namun, banyak hal yang dapat dijadikan suatu bahan untuk mengembangkan karakter peserta didik, salah satunya dapat direalisasikan melalui seni dan kebudayaan.

Setiap daerah di Indonesia pasti memiliki seni dan kebudayaan masing-masing. Layaknya daerah lain, Kabupaten Ponorogo juga memiliki seni dan kebudayaannya sendiri yang menjadi ciri khas kabupaten ini. Motif batik merupakan salah satu khazanah seni dan budaya Kabupaten Ponorogo. Motif batik Ponorogo yang beraneka, memiliki makna filosofis berbeda antara satu dengan yang lain (Maharani, et al., 2020; Mawardhi, D. 2018). Motif batik adalah kerangka gambar pada batik berupa perpaduan antara garis, bentuk, dan isen menjadi satu kesatuan yang mewujudkan batik secara keseluruhan. Motif batik disebut juga corak batik atau pola batik (Trixie, 2020; Ulum, 2018). Motif-motif batik tersebut antara lain motif hewan, manusia, dan geometris. Membatik merupakan tradisi turun-temurun. Oleh karena itu, motif batik sering menjadi ciri khas suatu keluarga atau daerah tertentu. Menurut studi pendahuluan yang peneliti lakukan beberapa kajian terdahulu menemukan bahwa, bahwa ada salah satu motif batik bernama Kijing Miring yang mengandung nilai pendidikan karakter religious dan sebagai refleksi karatker masyarakat (Kartikasari, 2017; Maulida, D. R., \& Agustin, S. A. 2020). Motif Kijing Miring diilhami dari bentuk 
segitiga batu nisan dan bentuk piramida di Mesir yang merupakan makam dari rajaraja sehingga motif ini ditujukan sebagai pengingat agar setiap manusia ingat mati. Dengan demikian, diasumsikan motif batik Ponorogo juga sarat dengan nilai-nilai filosofis yang bisa dimanfaatkan untuk pembangunan karakter.

Berdasarkan latar belakang di atas, penelitian berjudul "Analisis Makna Filosofis Motif Batik Ponorogo Sebagai Upaya Penanaman Pendidikan Karakter" ini penting dilakukan dengan beberapa pertimbangan berikut; (1) mendukung upaya pemerintah terkait dengan tujuan pendidikan nasional yang terdapat dalam UU No. 20 Tahun 2003, salah satunya adalah dengan penerapan pendidikan karakter; (2) menggali khazanah batik Ponorogo kaitannya dengan pendidikan karakter; dan (3) media sosialisasi peserta didik SMA di Kabupaten Ponorogo mengenai pendidikan karakter yang terkandung dalam motif batik Ponorogo. Tujuan dari penelitian ini adalah Mendeskripsikan secara ilmiah nilai-nilai pendidikan karakter pada makna filosofis motif batik Ponorogo dan mengetahui pemahaman peserta didik SMA di Kabupaten Ponorogo tentang makna filosofis motif batik Ponorogo terhadap nilai-nilai pendidikan karakter.

\section{METODE PENELITIAN}

Dalam penelitian ini, peneliti menggunakan metode deskriptif. Menurut Notoatmodjo (2005) metode deskriptif yaitu suatu metode penelitian yang dilakukan dengan tujuan utama untuk membuat gambaran tentang suatu keadaan yang objektif. Adapun pendekatan dalam penelitian ini adalah pendekatan kualitatif. Pendekatan kualitatif merupakan pendekatan yang tidak menggunakan data berupa angka atau statistik dalam mendeskripsikan laporan penelitian. Metode ini mempunyai keunggulan mampu menemukan teori baru untuk setting kebudayaan yang diteliti (Purwanto, 2010). Adapun alir penelitian ini adalah sebagai berikut:

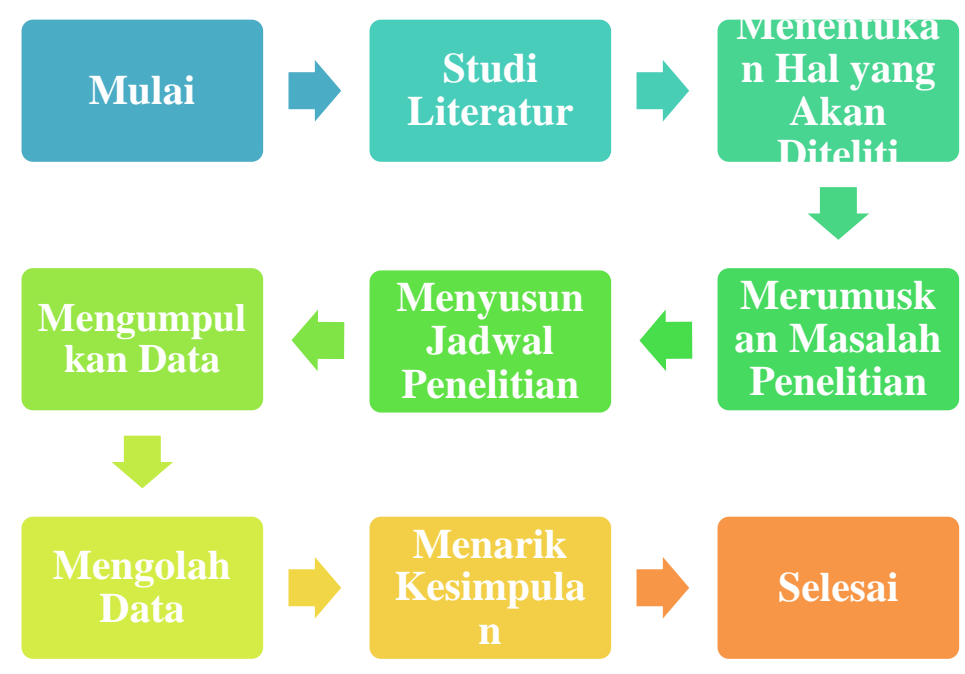

Gambar 1: Diagram alur penelitian

Peneliti mengambil sampel dari pakar seni batik dan peserta didik SMA di Kabupaten Ponorogo (dengan teknik angket) sebagai objek dari penelitian ini. Data merupakan sumber informasi yang didapatkan oleh peneliti melalui penelitian yang dilakukan. Data yang diperoleh nantinya akan diolah sehingga menjadi informasi baru 
yang dapat dimanfaatkan oleh pembacanya. Dalam penelitian ini, data diperoleh melalui dua sumber, yaitu data primer dan data sekunder.Data primer yaitu data yang diperoleh secara langsung dari narasumber. Dalam penelitian ini, data primer diperoleh melalui hasil wawancara dengan narasumber (indepht intervie atau wawancara mendalam). Data sekunder yaitu data yang diperoleh peneliti untuk mendukung data primer. Data sekunder ini seperti buku-buku, studi dokumen, jurnal ilmiah, dan data kuantitatif dari hasil angket kepada seratus peserta didik SMA di Kabupaten Ponorogo.

Teknik pengumpulan data yang digunakan dalam penelitian ini adalah : Studi kepustakaan (library research) merupakan metode pengumpulan data yang diarahkan kepada pencarian data dan informasi melalui dokumen-dokumen, baik dokumen tertulis, foto-foto, gambar, maupun dokumen elektronik yang dapat mendukung dalam proses penulisan. Hasil penelitian juga akan semakin kredibel apabila didukung foto-foto atau karya tulis akademik dan seni yang telah ada (Sugiyono, 2005). Observasi merupakan teknik pengumpulan data dengan cara melakukan pengamatan tentang keadaan yang ada di lapangan. Dengan melakukan observasi, peneliti menjadi lebih memahami tentang subjek dan objek yang sedang diteliti. Dalam penelitian ini, peneliti langsung berperan pada proses pengumpulan data sehingga observasi yang dilakukan bersifat partisipatif. Indepht interview atau wawancara mendalam merupakan salah satu cara untuk mendapatkan informasi dengan bertatap muka antara pewawancara dengan narasumber. Hal tersebut sesuai dengan yang dikemukakan (Sugiyono, 2005) bahwa wawancara digunakan sebagai teknik pengumpulan data apabila peneliti ingin mengetahui hal-hal dari narasumber yang lebih mendalam

\section{HASIL DAN PEMBAHASAN}

Untuk mengetahui nilai pendidikan karakter yang terkandung dalam motif batik Ponorogo dari hasil wawancara peneliti dengan narasumber pakar seni batik Ponorogo yang bernama Bapak Mohammad Ali Muchlisoni secara rinci dapat dilihat pada uraian berikut:

\section{Motif Gebyar}

Batik yang dinamakan Gebyar ini memiliki makna yaitu gebyar yang mempunyai arti semarak (gambar 1). Motif batik Gebyar yang divisualisasikan melalui burung merak yang sedang mengepakkan sayapnya menggambarkan semangat hidup menuju kehidupan yang unggul dan mulia. Hal ini sejalan dengan nilai pendidikan karakter kerja keras.

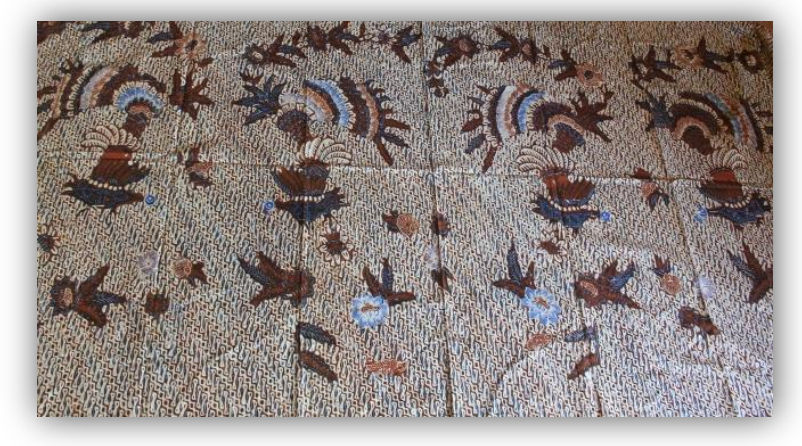

Gambar 1 Motif Gebyar

(Sumber: Dokumentasi Penelitian) 


\section{Motif Sekar Jagat}

Batik yang dinamakan Sekar Jagat ini bermotifkan berbagai macam motif berkumpul menjadi satu (gambar 2). Motif batik Sekar Jagat yang divisualisasikan melalui paduan berbagai macam motif menggambarkan keanekaragaman dalam kehidupan. Motif ini memiliki makna yang sangat dalam tentang indahnya keanekaragaman ketika dimanfaatkan untuk saling mengisi dan menghargai. Dalam konteks Indonesia, motif Sekar Jagat ini memiliki relevansi dengan fakta kehidupan multikultural di negeri tercinta ini yang apabila dibalut dengan semangat berbagi akan melahirkan kehidupan penuh damai dan cinta kasih. Oleh karena itu, motif ini sangat mendukung pendidikan karakter toleransi.

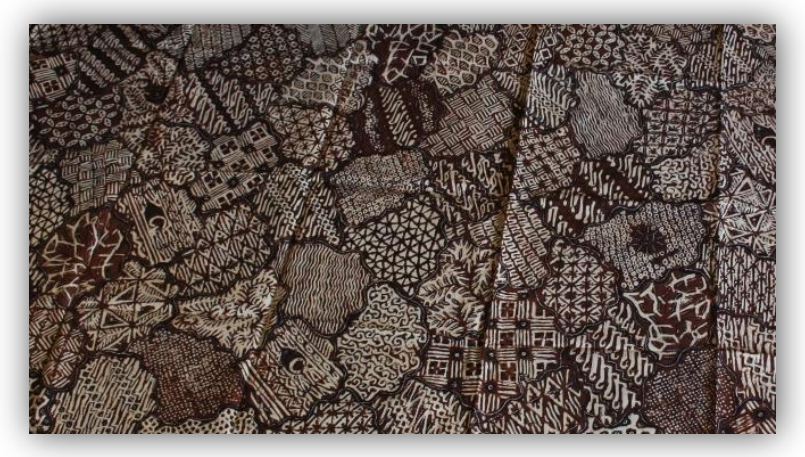

Gambar 2 Motif Sekar Jagat

(Sumber: Dokumentasi Penelitian)

\section{Motif Rujak Senthe}

Batik yang dinamakan Rujak Senthe merupakan kombinasi dari berbagai macam motif batik seperti parang, truntum, dan gedheg yang disusun secara miring (gambar 3.3). Motif Rujak Senthe yang divisualisasikan melalui kombinasi berbagai macam motif menggambarkan warna kehidupan yang saling beriringan, yaitu kebahagian dan ujian. Motif ini memiliki makna filosofis bahwa bahwa sebuah kebahagian hidup tidak akan pernah datang begitu saja, tetapi harus diaraihnya setelah berhasil menghadapi ujian dan cobaan. Dengan demikian, motif Rujak Senthe ini sesuai dengan nilai pendidikan karakter cinta damai.

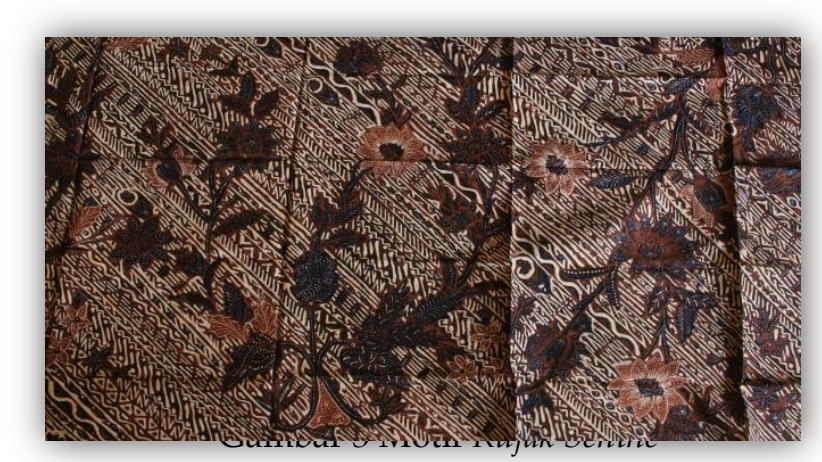

\section{Motif Tahu Tempe}

(Sumber: Dokumentasi Penelitian)

Batik yang dinamakan Tahu Tempe ini memiliki bentuk seperti tahu tempe sejenis makanan (gambar 3.4). Motif Tahu Tempe yang divisualisasikan dengan tahu dan tempe menggambarkan kesederhanaan dan kebersahajaan. Kata kunci pola hidup seperti ini akan melahirkan simpatik dan empatik terhadap sesama sehingga akan 
berdampak pada sikap hidup berbagi kebahagian dan kemanfaatan. Dengan demikian, motif ini sangat mendukung nilai pendidikan karakter kepedulian sosial.

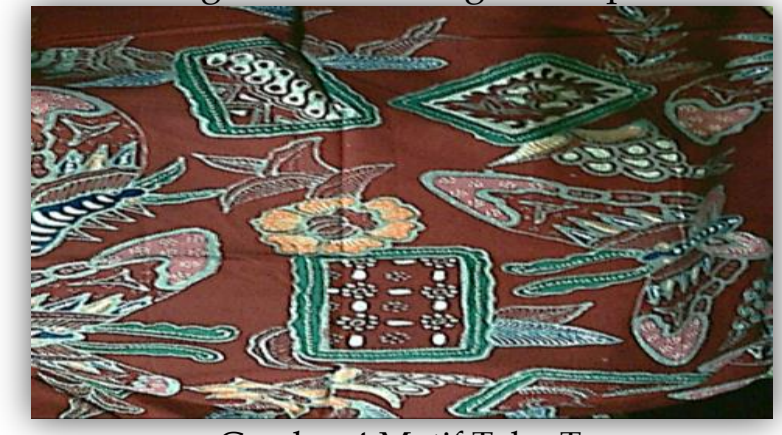

Gambar 4 Motif Tahu Tempe

(Sumber: Dokumentasi Penelitian)

\section{Motif Kopi Pecah}

Batik yang dinamakan Kopi Pecah ini biasanya juga disebut dengan Ketumbar Bolong (gambar 3.5). Motif Kopi Pecah yang divisualisasikan dengan biji kopi berwarna hitam yang tersusun secara rapi menggambarkan prinsip hidup yang kuat dan penuh kemanfaatan. Warna hitam pada biji kopi menggambarkan karakter kuat, bersahaja, dan penuh semangat, sedangkan rasa pahit sebagai rasa asli biji kopi mengandung kandungan kafein, riboflavin, dan kandungan lainnya yang bermanfaat bagi tubuh manusia. Dengan demikian, motif batik Kopi Pecah ini sejalan dengan salah satu nilai yang terkandung dalam pendidikan karakter, yaitu tanggung jawab.

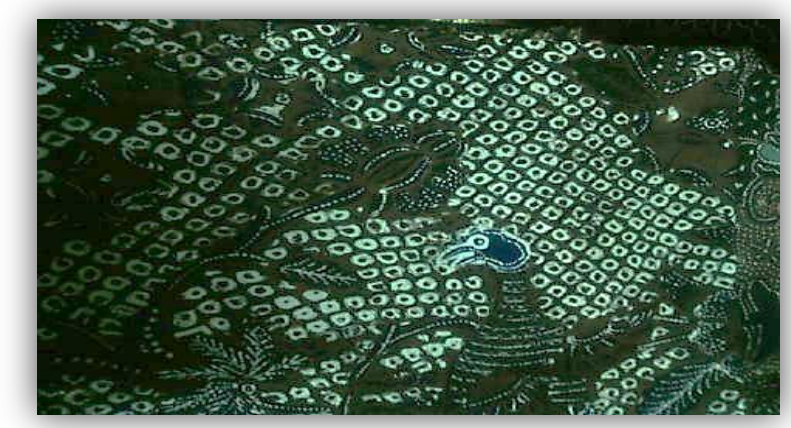

Gambar 5 Motif Kopi Pecah

(Sumber: Dokumentasi Penelitian)

\section{Motif Esuk Sore}

Batik yang dinamakan Esuk Sore ini memiliki latar berwarna gelap dan terang (gambar 3.6). Motif Esuk Sore ini divisualisasikan dengan suasana gelap dan terang menggambarkan kehidupan manusia yang tidak lepas dari dua hal yang harus dihadapi dalam kehidupan dunia yang fana ini, yaitu kebaikan dan keburukan, dimaksudkan agar manusia selalu waspada dalam menjalani kehidupan ini, dengan selalu komitmen dijalan kebaikan menuju ketakwaan kepada Tuhan Yang Maha Esa. Oleh karena itu, makna filosofis motif batik Esuk Sore ini relevan dengan salah satu nilai pendidikan karakter, yaitu religius. 


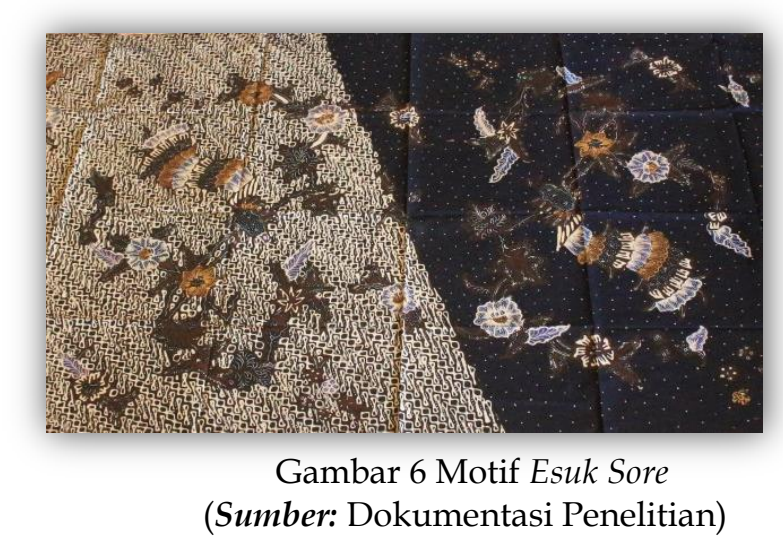

\section{Motif Jarot Asem}

Batik yang dinamakan Jarot Asem ini memiliki bentuk seperti buah asem (gambar 7). Motif Jarot Asem yang divisualisasikan dengan buah asem berserabut panjang dan saling berkait antarserabut atau jarotnya menggambarkan keharusan manusia sebagai makhluk sosial yang harus hidup saling berhubungan dan tolongmenolong menuju masyarakat yang damai dan harmonis. Dengan demikian, motif batik ini sesuai dengan salah satu unsur yang terdapat dalam pendidikan karakter, yaitu persahabatan atau komunikatif.

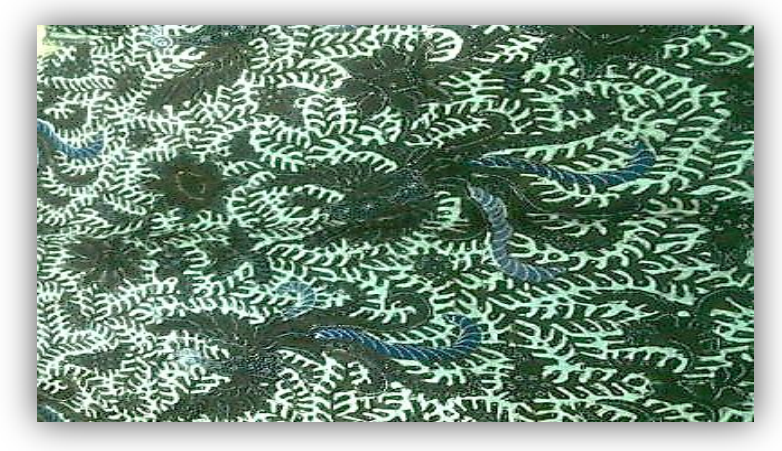

Gambar 7 Motif Jarot Asem

(Sumber: Dokumentasi Penelitian)

Dari hasil wawancara di atas, dapat disimpulkan bahwa semua motif batik Ponorogo yang telah dikaji mengandung makna filosofis yang dapat dijadikan sebagai bahan pembelajaran pendidikan karakter. Masing-masing motif memiliki nilai pendidikan karakter yang berbeda-beda; (1) motif Gebyar mengandung nilai karakter kerja keras; (2) motif Sekar Jagat mengandung nilai karakter toleransi; (3) motif Rujak Senthe mengandung nilai karakter cinta damai; (4) motif Tahu Tempe mengandung nilai karakter peduli sosial; (5) motif Kopi Pecah mengandung nilai karakter tanggung jawab; (6) motif Esuk Sore mengandung nilai karakter religius; (7) motif Jarot Asem mengandung nilai karakter persahabatan atau komunikatif, yang kesemuanya menggambarkan kepribadian utama manusia. Dengan demikian, makna filosofis motif batik Ponorogo sesuai dengan nilai-nilai pendidikan karakter.

Untuk mengetahui pemahaman peserta didik SMA di Kabupaten Ponorogo tentang makna filosofis motif batik Ponorogo terhadap nilai-nilai pendidikan karakter, peneliti melakukan uji empiris dengan menggunakan instrumen berupa angket yang dibuat melalui google formulir sehingga dapat diakses secara online dan memudahkan untuk mengumpulkan hasilnya. Angket ini tetap dijaga keakuratannya karena 
prosesnya melalui pengiriman langsung ke responden, yaitu peserta didik SMA di Kabupaten Ponorogo. Berikut pernyataaan-pernyataan instrumen yang diajukan kepada responden:

1. Motif Gebyar

Batik yang dinamakan Gebyar ini memiliki makna yaitu gebyar yang mempunyai arti semarak (lihat gambar). Batik Gebyar itu termasuk jenis parang atau pereng. Parang ini memiliki makna petuah untuk tidak pernah menyerah dalam menghadapi apapun. Motif Gebyar ini erat kaitannya dengan nilai pendidikan karakter yaitu kerja keras.

2. Motif Sekar Jagat

Batik yang dinamakan Sekar Jagat ini bermotifkan berbagai macam motif berkumpul menjadi satu (lihat gambar). Motif Sekar Jagat melambangkan keanekaragaman yang ada dalam kehidupan yang kemudian menimbulkan keindahan. Motif ini memiliki arti bahwa keanekaragaman bukan sebagai penghalang untuk bersatu karena keanekaragaman sebenarnya menimbulkan sebuah keindahan. Motif Sekar Jagat mengajarkan bahwa sebagai manusia harus selalu menghargai sebuah perbedaan karena hal tersebut dapat melahirkan sebuah keindahan. Oleh karena itu, motif Sekar Jagat sesuai dengan nilai pendidikan karakter yaitu toleransi.

3. Motif Rujak Senthe

Batik yang dinamakan Rujak Senthe merupakan kombinasi dari berbagai macam motif batik seperti parang, truntum, dan gedheg yang disusun secara miring (lihat gambar). Arti dari Rujak Senthe mengingatkan kita pada kehidupan yang penuh dengan kebahagiaan tetapi selalu disertai dengan timbulnya berbagai cobaan. Motif ini selaras dengan salah satu nilai dalam pendidikan karakter, yaitu cinta damai.

4. Motif Tahu Tempe

Batik yang dinamakan Tahu Tempe ini memiliki bentuk seperti tahu tempe sejenis makanan (lihat gambar). Tahu Tempe bermakna kesederhanaan, bersahaja, dan bermanfaat. Manusia harusnya menjalani hidup seperti itu. Motif tersebut menggambarkan salah satu nilai yang terdapat pada pendidikan karakter, yaitu peduli sosial.

5. Motif Kopi Pecah

Batik yang dinamakan Kopi Pecah atau biasanya disebut dengan Ketumbar Bolong (lihat gambar). Kopi Pecah diibaratkan seperti kopi yang bijinya kecil, hitam, dan pahit sehingga memunculkan semangat hidup untuk mencapai tujuan hidup. Motif ini sejalan dengan salah satu nilai yang terkandung dalam pendidikan karakter, yaitu tanggung jawab.

6. Motif Esuk Sore

Batik yang dinamakan Esuk Sore tersebut memiliki latar berwarna gelap dan terang (lihat gambar). Motif Esuk Sore ini merupakan unsur kehidupan antara kebaikan dan keburukan. Unsur kehidupan antara kebaikan dan keburukan erat kaitannya dengan kedekatan seorang insan dengan Tuhan-Nya, sehingga motif ini relevan dengan salah satu nilai penting dalam pendidikan karakter, yaitu religius.

7. Motif Jarot Asem

Batik yang dinamakan Jarot Asem tersebut memiliki bentuk seperti buah asem (lihat gambar). Kalau kita lihat Jarot Asem bentuknya berserabut panjang dan saling bersinambung dengan jarot lain dalam satu buah. Hal ini berarti manusia 
harus saling tolong menolong sehingga tercipta kehidupan yang harmonis. Motif Jarot Asem menggambarkan salah satu unsur yang terdapat dalam pendidikan karakter, yaitu persahabatan atau komunikatif.

Pernyataan-pernyataan tersebut merupakan hasil dari wawancara dengan narasumber pakar seni batik Ponorogo yang bernama Bapak Mohammad Ali Muchlisoni. Selain terdapat pernyataan juga disertai gambar tentang motif batik yang dimaksud. Jawaban dari pernyataan-pernyataan tersebut dibuat dalam bentuk skala menggunakan skala Likert untuk mengukur opini atau persepsi responden berdasarkan tingkat pemahaman. Untuk analisis secara kuantitatif, alternatif jawaban tersebut diberi skor dari 1 (satu) sampai dengan nilai 5 (lima), dimana bila:

Skor 1 = Sangat Tidak Paham (STP)

Skor 2 = Tidak Paham (TP)

Skor 3 = Cukup Paham (CP)

Skor $4=$ Paham $(\mathrm{P})$

Skor $5=$ Sangat Paham $(\mathrm{SP})$

Adapun rumus dalam menentukan rentang skala (RS) menurut Simamora (2004) adalah sebagai berikut:

$$
\boldsymbol{R} \boldsymbol{S}=\frac{\boldsymbol{m}-\boldsymbol{n}}{\boldsymbol{b}}
$$

dimana: $m=$ angka tertinggi di dalam pengukuran (angka tertinggi dalam angket).

angket).

$n=$ angka terendah di dalam pengukuran (angka terendah dalam angket).

$$
b=\text { banyaknya kelas yang dibentuk (pilihan jawaban dalam }
$$

Dalam penelitian ini Rentang Skala $=0,8$, maka untuk menginteprestasikan rata-rata tanggapan responden pengguna adalah sebagai berikut:
Nilai skor antara 1 s.d. $\leq 1,8$
Nilai skor antara $>1,8$ s.d. $\leq 2,6$
Sangat Tidak Paham
Nilai skor antara $>2,6$ s.d. $\leq 3,4$
Tidak Paham
Nilai skor antara $>3,4$ s.d. $\leq 4,2$
Cukup Paham
Paham
Nilai skor diatas 4,2
Sangat Paham

Metode analisis data kuantitatif yang digunakan dalam penelitian ini adalah Analisis Deskriptif Persentase. Deskriptif persentase ini diolah dengan cara frekuensi dibagi dengan jumlah responden dikali 100 persen, seperti dikemukakan Sudjana (2001 :129) adalah sebagai berikut:

Keterangan:

$$
P=\frac{f}{N} \times 100 \%
$$

$$
\begin{aligned}
P & : \text { Persentase } \\
f & : \text { Frekuensi } \\
N & : \text { Jumlah Responden } \\
100 \% & : \text { Bilangan tetap }
\end{aligned}
$$

Penghitungan deskriptif persentase ini dilakukan dengan pengumpulan jawaban responden lalu menghitung frekuensi untuk dimasukkan ke dalam rumus, dan terakhir adalah penarikan kesimpulan dari hasil tersebut. Hasil uji angket online mengenai pemahaman peserta didik SMA Kabupaten Ponorogo tentang makna filosofis motif batik Ponorogo terhadap nilai-nilai pendidikan karakter adalah sebagai berikut: 

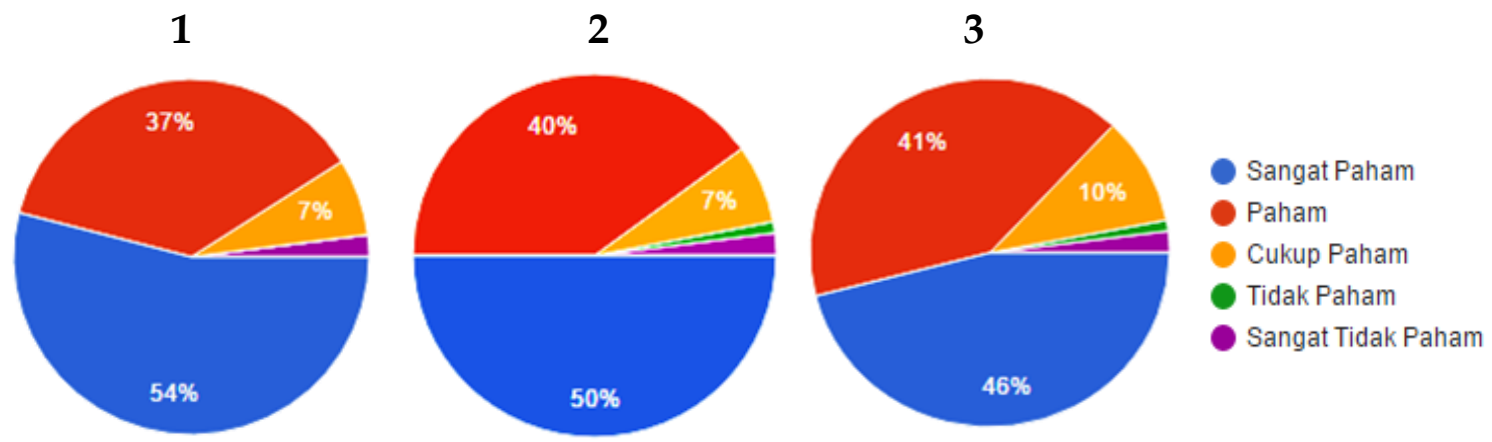

Gambar 8. Tanggapan Peserta Didik SMA Ponorogo Terhadap Pernyataan Nomor 1-3
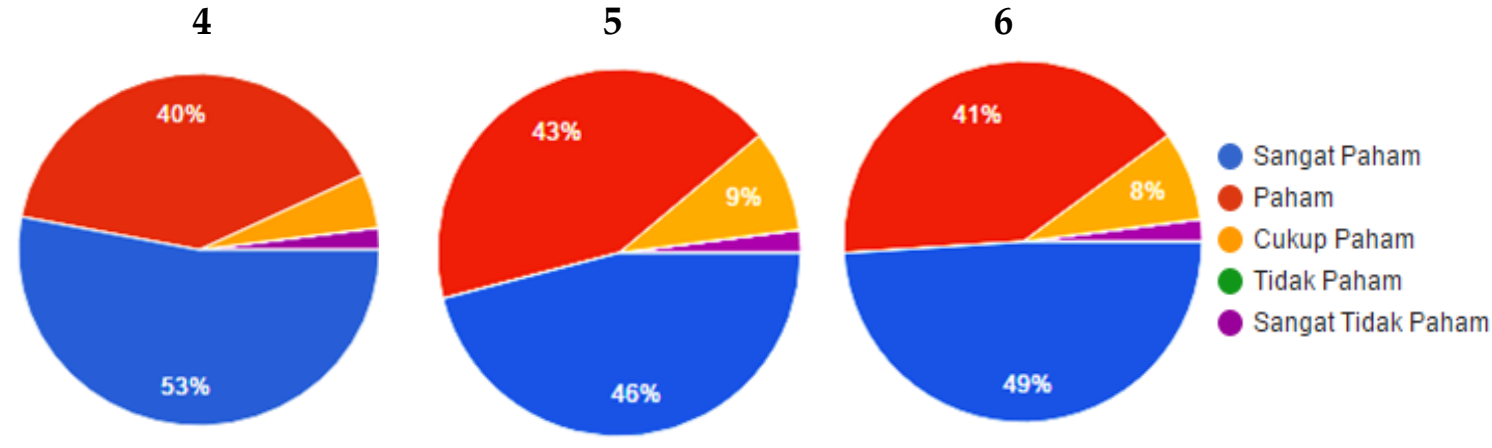

Gambar 9 Tanggapan Peserta Didik SMA Ponorogo Terhadap Pernyataan Nomor 4-6
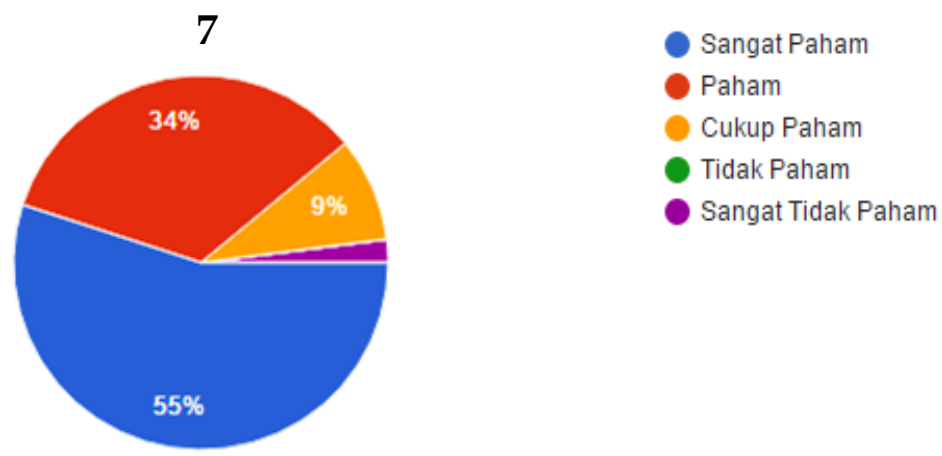

Gambar 10 Tanggapan Peserta Didik SMA Ponorogo Terhadap Pernyataan Nomor 7

Berdasarkan diagram di atas, ditunjukkan bahwa responden rata-rata sangat paham dengan tiap-tiap pernyataan yang telah diajukan sehingga berdasarkan data tersebut, dapat dihitung skor tanggapan pengguna terhadap seluruh pernyataan yang telah diajukan. Penghitungan skor dapat dilihat pada tabel berikut: 
Tabel 1 : Data Hasil Rekap Angket

\begin{tabular}{|c|c|c|c|c|}
\hline No & Pernyataan & Jumlah & Rata - Rata & \multirow{2}{*}{$\begin{array}{l}\text { Keterangan Skor : } \\
\mathrm{SP}=5 \\
\mathrm{P}=4\end{array}$} \\
\hline 1 & $\begin{array}{c}\text { Pernyataan nomor } \\
1\end{array}$ & $\begin{array}{c}(54 \times 5)+(37 \times 4)+(7 \times \\
3)+(2 \times 1)=441\end{array}$ & $\frac{441}{100}=4,41$ & \\
\hline 2 & $\begin{array}{l}\text { Pernyataan nomor } \\
2\end{array}$ & $\begin{array}{c}(53 \times 5)+(40 \times 4)+(5 \times \\
3)+(2 \times 1)=442\end{array}$ & $\frac{442}{100}=4,42$ & $\begin{array}{l}\mathrm{CP}=3 \\
\mathrm{TP}=2 \\
\mathrm{TP}=1\end{array}$ \\
\hline 3 & $\begin{array}{l}\text { Pernyataan nomor } \\
3\end{array}$ & $\begin{array}{c}(46 \times 5)+(41 \times 4)+(10 \times \\
3)+(1 \times 2)+(2 \times 1)= \\
428\end{array}$ & $\frac{428}{100}=4,28$ & \\
\hline 4 & $\begin{array}{l}\text { Pernyataan nomor } \\
44\end{array}$ & $\begin{array}{c}(50 \times 5)+(40 \times 4)+(7 \times \\
3)+(1 \times 2)+(2 \times 1)=435\end{array}$ & $\frac{435}{100}=4,35$ & \\
\hline 5 & $\begin{array}{l}\text { Pernyataan nomor } \\
5\end{array}$ & $\begin{array}{c}(46 \times 5)+(43 \times 4)+(9 \times \\
3)+(2 \times 1)=431\end{array}$ & $\frac{431}{100}=4,31$ & \\
\hline 6 & $\begin{array}{l}\text { Pernyataan nomor } \\
6\end{array}$ & $\begin{array}{c}(49 \times 5)+(41 \times 4)+(8 \times \\
3)+(2 \times 1)=435\end{array}$ & $\frac{435}{100}=4,35$ & \\
\hline 7 & $\begin{array}{c}\text { Pernyataan nomor } \\
7\end{array}$ & $\begin{array}{c}(55 \times 5)+(34 \times 4)+(9 \times \\
3)+(2 \times 1)=440\end{array}$ & $\frac{440}{100}=4,4$ & \\
\hline
\end{tabular}

Sesuai dengan metode penelitian ini yang menggunakan Rentang Skala = 0,8 maka berdasarkan skor tiap pernyataan, dapat diketahui bahwa:

a. Peserta didik SMA di Kabupaten Ponorogo sangat paham bahwa motif Gebyar erat kaitannya dengan nilai pendidikan karakter yaitu kerja keras.

b. Peserta didik SMA di Kabupaten Ponorogo sangat paham bahwa motif Sekar Jagat sesuai dengan nilai pendidikan karakter yaitu toleransi.

c. Peserta didik SMA di Kabupaten Ponorogo sangat paham bahwa motif Rujak Senthe selaras dengan salah satu nilai dalam pendidikan karakter, yaitu cinta damai.

d. Peserta didik SMA di Kabupaten Ponorogo sangat paham bahwa motif Tahu Tempe menggambarkan salah satu nilai yang terdapat pada pendidikan karakter, yaitu peduli sosial.

e. Peserta didik SMA di Kabupaten Ponorogo sangat paham bahwa motif Kopi Pecah sejalan dengan salah satu nilai yang terkandung dalam pendidikan karakter, yaitu tanggung jawab.

f. Peserta didik SMA di Kabupaten Ponorogo sangat paham bahwa motif Esuk Sore relevan dengan salah satu nilai penting dalam pendidikan karakter, yaitu religius.

g. Peserta didik SMA di Kabupaten Ponorogo sangat paham bahwa motif Jarot Asem menggambarkan salah satu unsur yang terdapat dalam pendidikan karakter, yaitu persahabatan atau komunikatif.

Hasil penelitian ini menunjukkan bahwa peserta didik SMA di Kabupaten Ponorogo sangatlah paham dengan nilai-nilai pendidikan karakter yang terkandung pada motif batik Ponorogo. Ditinjau dari hasil rekap angket di atas, peserta didik SMA di Kabupaten Ponorogo sangat memahami pernyataan nomor tujuh yaitu makna filosofis motif batik Jarot Asem dengan rata-rata nilai jawaban 4,4, sedangkan pada pernyataan nomor tiga yaitu makna filosofis motif batik Rujak Senthe peserta didik 
SMA di Kabupaten Ponorogo kurang begitu memahami karena nilai rata-ratanya terendah dari ke tujuh pernyataan, yaitu sebesar 4,28.

Penelitian ini diperkuat oleh beberapa temuan terdahulu, Saputra, et al., (2021) bahwa motif batik dapat digunakan untuk menjadi salah satu media dalam pendidikan karakter di sekolah dasar karena dalam motif batik ngawi mempunyai makna makna sendiri yang bentuk saja memiliki nilai karakter di dalamnya. Motif batik yang memiliki makna seperti antara lain motif batik wahyu ngawiyatan yang mempunyai makna di berbagai motif, motif benteng pendem minim motif tetapi menggambarkan sejarah dan flora yang ada di Ngawi. Temuan Miranti, et al., (2021) tentang Representasi Pendidikan Karakter Berbassis Kearifan Lokal dalam Motif Batik Wahyu Ngawiyatan sebagai Muatan Pendidikan Senirupa di Sekolah Dasar. Bahwa Wujud pengembangan nilai karakter pada peserta didik yang berbasis kearifan lokal yaitu dengan merepresentasikan motif batik khas daerah yang memiliki filosofi sejarah dari daerah tersebut. Hasil representasi dari motif batik Wahyu Ngawiyatan ke dalam nilai-nilai pendidikan karakter berbasis kearifan lokal yaitu memiliki nilai religius, jujur, toleransi, disiplin, kerja keras, kreatif, mandiri, demokratis, rasa ingin tahu, semangat kebangsaan, cinta tanah air, menghargai prestasi, komunikatif, cinta damai, gemar membaca, peduli lingkungan, peduli sosial, dan tanggung jawab (Ghufronudin, G., Zuber, A., \& Demartoto, A. 2018). Salah satu kearifan lokal yang dapat dijadikan pembelajaran nilai karakter adalah seni batik yang merupakan budaya bangsa dengan ciri khas motif yang unik dan penuh makna simbolik (Sariyatun, 2018; Wijayaningputri, A. R., \& Regina, B. D. 2020). Berbagai jenis batik yang divisualisasikan ke dalam bentuk motif memiliki makna masing-masing yang jika direpresentasikan memiliki nilai-nilai yang dapat diajarkan kepada peserta didik menjadi suatu pendidikan karakter. Wujud pengembangan nilai pendidikan karakter pada peserta didik yang berbasis kearifan lokal yaitu dengan merepresentasikan motif batik khas daerah yang memiliki filosofi sejarah dari daerah tersebut.

Dengan demikian, makna filosofis motif batik Ponorogo ini memberikan kontribusi sebagai terobosan media pembelajaran pendidikan karakter melalui pendidikan nonformal. Peneliti berharap masyarakat Ponorogo khususnya peserta didik SMA Ponorogo tidak hanya melestarikan batik dengan menggunakannya saja, tetapi juga mampu memahami makna yang terkandung dalam batik yang dikenakannya.

\section{KESIMPULAN}

Berdasarkan hasil penelitian yang telah dilakukan peneliti kepada pakar seni batik yang bernama Bapak Mohammad Ali Muchlisoni dapat disimpulkan bahwa motif batik Ponorogo, meliputi; (1) motif Gebyar; (2) motif Sekar Jagat; (3) motif Rujak Senthe; (4) motif Tahu Tempe; (5) motif Kopi Pecah; (6) motif Esuk Sore; (7) motif Jarot Asem, mengandung nilai-nilai pendidikan karakter yang baik untuk memperkuat karakter peserta didik. Makna filosofis motif batik Ponorogo tersebut juga telah dipahami secara baik oleh peserta didik SMA di Kabupaten Ponorogo. Hal ini didukung dengan hasil uji angket online yang peneliti lakukan kepada peserta didik SMA di Kabupaten Ponorogo diperoleh hasil bahwa mereka sangat paham dengan makna filosofis yang terkandung dalam setiap motif batik Ponorogo terhadap nilainilai pendidikan karakter. Adapun saran untuk pembaca agar dapat menindaklanjuti hasil penelitian ini sebagai bahan referensi dalam melakukan penelitian lanjutan. Selain itu, hasil penelitian ini diharapkan dapat menjadi salah satu alternatif media pembelajaran tentang pendidikan karakter di sekolah-sekolah. Dengan demikian, 
peserta didik lebih mudah memahami dan mencintai budaya serta mengetahui maknamakna yang terkandung didalamnya.

\section{UCAPAN TERIMAKASIH}

Peneliti mengucapkan terima kasih kepada guru, peserta didik SMA di Kabupaten Ponorogo dan para pakar seni batik di Kabupaten Ponorogo. Peneliti juga mengucapkan terima kasih kepada Dewan Editor Attractive: Innovative Education Journal yang telah memberikan peer review process dan saran dalam penyempurnaan naskah artikel jurnal. Sehingga layak untuk dipublikasikan.

\section{PERNYATAAN KONTRIBUSI PENELITIAN}

Penelitian ini dilakukan oleh Galih Puji Kurniawan (GPK), Haura Almash Aulia Shofwana (HAS). GPK dan HAS mengolah data kemudian menyelesaikan proses revisi dan penyempurnaan naskah artikel.

\section{REFERENCES}

Cahyono, H., Suhono, S., \& Khumairo, A. (2018). Pendidikan Karakter Bagi Pelaku Pedofilia (sebuah Strategi dalam Mengatasi Amoral). JMKSP (Jurnal Manajemen, Kepemimpinan, dan Supervisi Pendidikan), 3(1), 1-19.

Elihami, E., \& Syahid, A. (2018). Penerapan Pembelajaran Pendidikan Agama Islam Dalam Membentuk Karakter Pribadi Yang Islami. Edumaspul: Jurnal Pendidikan, 2(1), 79-96.

Gunawan, I. I., \& Gunawan, I. (2019, December). Develop Educational Leadership by Applying Values and Ethics to Strengthen Student Character. In 5th International Conference on Education and Technology (ICET 2019) (pp. 23-29). Atlantis Press.

Ghufronudin, G., Zuber, A., \& Demartoto, A. (2018). Representasi Pendidikan Karakter Berbasis Kearifan Lokal Melalui Pembelajaran Membatik. Jurnal Pendidikan Karakter JAWARA (Jujur, Adil, Wibawa, Amanah, Religius, Akuntabel), 4(1).

Maunah, B. (2015). Implementasi pendidikan karakter dalam pembentukan kepribadian holistik siswa. Jurnal Pendidikan Karakter, (1).

Maharani, D. A., Parji, P., \& Sudarmiani, S. (2020). The Developmental History of Ponorogo Batik Motif and Its Educational Values. Social Sciences, Humanities and Education Journal (SHE Journal), 1(1), 1-9.

Maulida, D. R., \& Agustin, S. A. (2020). Perancangan Buku Visual Batik Gedog sebagai Media Pelestarian Motif Batik Tuban. Jurnal Sains dan Seni ITS, 9(1), F72-F78.

Mawardhi, D. (2018). Perancangan Buku Visual Eksplorasi Motif Batik Ponorogoan sebagai Upaya Pelestarian Warisan Budaya Daerah (Doctoral dissertation, Institut Teknologi Sepuluh Nopember).

Muchtar, D., \& Suryani, A. (2019). Pendidikan Karakter Menurut Kemendikbud. Edumaspul: Jurnal Pendidikan, 3(2), 50-57.

Miranti, A., Lilik, L., Winarni, R., \& Surya, A. (2021). Representasi Pendidikan Karakter Berbassis Kearifan Lokal dalam Motif Batik Wahyu Ngawiyatan sebagai Muatan Pendidikan Senirupa di Sekolah Dasar. Jurnal basicedu, 5(2), 546-560.

Pohling, R., Bzdok, D., Eigenstetter, M., Stumpf, S., \& Strobel, A. (2016). What is ethical competence? The role of empathy, personal values, and the five-factor model of personality in ethical decision-making. Journal of Business Ethics, 137(3), 449-474.

Wuryani, M. T. (2018). Textbooks Thematic Based Character Education on Thematic Learning Primary School: An Influence. International Journal of Educational Methodology, 4(2), 75-81. 
Wulandari, Y., \& Kristiawan, M. (2017). Strategi sekolah dalam penguatan pendidikan karakter bagi siswa dengan memaksimalkan peran orang tua. JMKSP (Jurnal Manajemen, Kepemimpinan, dan Supervisi Pendidikan), 2(2), 290-302

Kartikasari, D. W. (2017). Makna motif Batik Gedog sebagai refleksi karakter masyarakat Tuban. Kajian Moral dan Kewarganegaraan, 5(03).

Kristiawan, M., Suhono, S., Yussof, M. H. B., \& Muslimah, M. (2021). The International School's Culture in Indonesia and Brunei Darussalam. Jurnal Iqra': Kajian Ilmu Pendidikan, 6(1), 180-191.

Kristiawan, M., Ahmad, S., Tobari, T., \& Suhono, S. (2017). Desain Pembelajaran SMA Plus Negeri 2 Banyuasin III Berbasis Karakter Di Era Masyarakat Ekonomi ASEAN. Jurnal Iqra': Kajian Ilmu Pendidikan, 2(2), 403-432.

Sariyatun, S. (2018). Pantulan Budaya Lokal "Makna Filosofis dan Simbolisme Motif Batik Klasik" untuk Penguatan Pendidikan Karakter. Jurnal Pendidikan Sejarah Indonesia, 1(1), 23-39.

Saputra, R. Y., Kurniawan, S. B., Rintayati, P., \& Mindrati, E. (2021). Motif Batik dalam Pendidikan Karakter Pasa Siswa Sekolah Dasar Kabupaten Ngawi. Jurnal basicedu, 5(2), 596-604.

Syafutra, S., Montessori, M., \& Suhono, S. (2021). Local Awareness in Making Social Integration of Society at Mendahara District. JMKSP (Jurnal Manajemen, Kepemimpinan, dan Supervisi Pendidikan), 6(2), 278-292.

Trixie, A. A. (2020). Filosofi Motif Batik Sebagai Identitas Bangsa Indonesia. Folio, 1(1), 1-9.

Ulum, B. (2018). Etnomatematika pasuruan: Eksplorasi geometri untuk sekolah dasar pada motif batik Pasedahan Suropati. Jurnal Review Pendidikan Dasar: Jurnal Kajian Pendidikan Dan Hasil Penelitian, 4(2), 686-696.

Wijayaningputri, A. R., \& Regina, B. D. (2020). Visualisasi dan Makna Filosofi Motif Batik Teratai di Galeri Soendari Berbasis Penguatan Pendidikan Karakter. JP2SD (Jurnal Pemikiran dan Pengembangan Sekolah Dasar), 8(2), 148-156.

Copyright Holder :

(C) Kurniawan, G., \& Shofwana, H., (2021).

First Publication Right :

(C) Attractive : Innovative Education Journal

This article is under:

(ㅇ) (1) (2) 